\title{
Concentrations of cytokinin and the use of agricultural residues in the in vitro propagation media of highbush blueberry
}

\author{
Michele Carla Nadal ${ }^{*}$ (iD) Adriane Marinho de Assis ${ }^{2}$ Dianini Brum Frölech ${ }^{2}$ (D) \\ Bruna Andressa dos Santos Oliveira ${ }^{2}$ Cari Rejane Fiss Timm² Márcia Wulff Schuch ${ }^{2}$
} ${ }^{1}$ Departamento de Agricultura, Universidade Federal de Lavras (UFLA), Lavras, MG, Brasil. E-mail: michecn@gmail.com. *Corresponding author.
${ }^{2}$ Departamento de Fitotecnia, Faculdade de Agronomia Eliseu Maciel, Universidade Federal de Pelotas (UFPEL), Pelotas, RS, Brasil.

ABSTRACT: The objective of the research was to evaluate cytokinin concentrations and agricultural residues as physical structuring agents of the culture medium in the in vitro propagation of highbush blueberry (Vaccinium corymbosum 'Duke'). To that end, three different concentrations of 2-isopentenyladenine (2iP) $\left(0,5\right.$, and $\left.10 \mathrm{mg} \mathrm{L}^{-1}\right)$ in woody plant medium (WPM) and five structuring agents (in natura rice husks, carbonized rice husks, coconut fiber, $S-10$ Beifort ${ }^{\circledR}$, and agar)were tested. After 60days of culture, the following parameters were evaluated: survival (\%),sprout and shoot lengths (cm),propagation rate, number of sprouts, and shoot dry mass ( $\mathrm{g}$ ). The substrates used as structuring agents were analyzed in terms of pH and electrical conductivity. The in natura rice husk, S-10 Beifort ${ }^{\circledR}$, and carbonized rice husk did not differ from the agar in terms of the sprout length. The shoots were longer $(1.64 \mathrm{~cm})$ in cultures within natura rice husk than in other treatments. In the absence of $2 \mathrm{iP}, \mathrm{S}-10$ Beifort ${ }^{\circledR}$ resulted in the highest propagation rate (2.97). Concerning the number of sprouts, $S$ - 10 Beifort ${ }^{\circledR}$, in natura rice husks, and carbonized rice husks did not differ from agar. However, when the regulator was added, the agar performed better in comparison to the other residues. Thus, in natura rice husks, carbonized rice husks, and S-10 Beifort ${ }^{\circledR}$ are potential physical structuring agents of the culture medium that can be used without $2 i P$.

Key words: $2 i$, tissue culture, physical structurers, Vaccinium corymbosum.

Concentrações de citocinina e uso de resíduos agrícolas no meio de multiplicação in vitro de mirtileiro

RESUMO: O objetivo deste trabalho foi avaliar concentrações de citocinina e resíduos agrícolas como agentes físicos de estruturação do meio na multiplicação in vitro de mirtileiro (Vaccinium corymbosum) 'Duke'. Para isso, foram testadas três concentrações de 2-isopenteniladenina (2iP) (0; 5 e $\left.10 \mathrm{mg} \mathrm{L}^{-1}\right)$ no meio WPM (Wood Plant Media); e cinco agentes estruturantes (casca de arroz in natura, casca de arroz carbonizada, fibra de coco, $S$-10 Beifort ${ }^{\mathbb{R}}$ e ágar). Após 60 dias foram avaliados: sobrevivência (\%); comprimento de brotações e de parte aérea (cm); taxa de multiplicação; número de brotações e massa seca de parte aérea (g). Analisou-se os substratos utilizados como agentes estruturantes quanto ao pH e condutividade elétrica. A casca de arroz in natura, o S-10 Beifort ${ }^{\circledR}$, e a casca de arroz carbonizada não diferiram do ágar quanto ao comprimento de brotações. Na casca de arroz in natura obteve-se o maior comprimento de parte aérea (1,64 cm), diferindo dos demais tratamentos. Na ausência de 2iP o S-10 Beifort $t^{\mathbb{R}}$ apresentou a maior taxa de multiplicação (2,97). Para o número de brotações o S-10 Beifort ${ }^{\mathbb{R}}$, a casca de arroz in natura e carbonizada não diferiram do ágar. Entretanto, quando acrescido de regulador, o ágar apresenta um desempenho maior em relação aos resíduos. Sendo assim, a casca de arroz in natura, a casca de arroz carbonizada, e o $S$-10 Beifort ${ }^{\mathbb{R}}$ apresentam-se como potencias estruturadores físicos do meio de cultura, podendo ser utilizados sem o uso de $2 i P$.

Palavras-chave: 2iP, cultura de tecidos, estruturadores fisicos, Vaccinium corymbosum.

\section{INTRODUCTION}

Native to North America, the high bush blueberry (Vaccinium corymbosum) has fruits appreciated for their exotic flavor and nutraceutical properties, especially in Europe, Asia and some regions of the Pacific, and South America
(RETAMALES \& HANCOCK, 2018). In Brazil, this fruit tree has been researched and produced in the South Region as an alternative in farm diversification, due to the high economic returns in a short timeframe (DAMIANI \& SCHUCH, 2008). Among the cultivars used in the South is Duke, a tetraploid plant that requires an exposure to a long chilling period for 
profitable growth and production. Other species, less demanding in chilling requirement, are becoming popular for cultivation in the Southeast Region of the country (CANTUARIAS-AVILES et al., 2014).

The highbush blueberry can be propagated by stem cuttings or micropropagation. Micropropagation is an effective technique, ensuring higher quality seedlings and shorter production time (DAMIANI \& SCHUCH, 2008; PELIZZA et al., 2013), as well as better use of physical space. However, compared with stem cuttings, micropropagation is a more expensive process (JUNGHANS\& SOUZA, 2013).

In order to reduce the costs of micropropagation, research to replace reagents such as agar with alternative solidifying materials for culture media that also allow for adequate development of the explants has been conducted. For example, GOLLE et al. (2010) experimented with corn starch, vermiculite, filter paper, and hydrophilic cotton for micropropagation of the loblolly pine (Pinus taeda), CURTI \& REINIGER (2014) tested vermiculite, Plantmax ${ }^{\circledR}$, and fine sand in yellow poinciana (Peltophorum dubium), OLIVEIRA et al. (2015a, 2015b) tested corn starch and cassava starch in pineapple (Ananas comosus), and RODRIGUES et al. (2016) and NADAL et al. (2018) assessed the use of coconut fiber, carbonized rice husk, and in natura rice husk for propagation of golden rain orchid (Oncidium baueri).

The use of agro-industrial residues as substrates can help to reduce the costs of different processes, while eliminating the materials accumulated in the environment (ASSIS et al., 2011; OLIVEIRA et al. 2018). However, there is little information on the use of residues as physical structuring agents of culture media and their possible interactions with the commonly used growth regulators such as cytokinins. The cytokinin 2-isopentenyladenine (2iP) enables a superior development of $V$. corymbosum ( $\mathrm{SCHUCH}$ et al., 2008). However, there is no information on the effect of this cytokinin on micropropagation with different structuring agents, with the exception of agar.

Therefore, the present research aimed to evaluate concentrations of $2 \mathrm{iPand}$ the use of different agricultural residues as physical structuring agents of the culture medium in the in vitro propagation of the highbush blueberry cultivar 'Duke'.

\section{MATERIALS AND METHODS}

Sprouting segments of the high bush blueberry 'Duke', were collected from established plants at Federal University of Pelotas, Capão do
Leão, Rio Grande do Sul, Brazil. The segments, each with two axillary buds, were used as explants and cultivated in vitro for 90 days in a growth chamber under a photoperiod of $16 \mathrm{~h}$, temperature of $25 \pm 2$ ${ }^{\circ} \mathrm{C}$, and light intensity of $27 \mu \mathrm{mol} \mathrm{m} \mathrm{m}^{-2} \mathrm{~s}^{-1}$.

The experimental design was entirely random, in a bifactorial scheme. The factors evaluated included three concentrations of $2 \mathrm{iP}(0,5$, and $10 \mathrm{mg}$ $\left.\mathrm{L}^{-1}\right)$ and five physical structuring agents: in natura rice husk $\left(0.2 \mathrm{~g} \mathrm{~mL}^{-1}\right)$, carbonized rice husk $(0.4 \mathrm{~g}$ $\left.\mathrm{mL}^{-1}\right)$, coconut fiber type 11 Amafibra $^{\circledR}\left(0.6 \mathrm{~g} \mathrm{~mL}^{-1}\right)$, S-10 Beifort ${ }^{\circledR}\left(1.3 \mathrm{mg} \mathrm{L}^{-1}\right)$, and agar $\left(6 \mathrm{~g} \mathrm{~L}^{-1}\right)$. In total, there were 15 treatments, with six repetitions and five explants per repetition.

Woody plant medium (WPM) (LLOYD \& MCCOWN, 1980), containing $0.1 \mathrm{~g} \mathrm{~L}^{-1}$ of myoinositol and $30 \mathrm{~g} \mathrm{~L}^{-1}$ of sucrose, was used as culture medium. After adjusting its $\mathrm{pH}$ to $5.0,30 \mathrm{~mL}$ of the liquid culture medium was poured into $300 \mathrm{~mL}$ glass flaks holding the structuring agents. Flasks were autoclaved at $120^{\circ} \mathrm{C}$ and $1.5 \mathrm{~atm}$ for $20 \mathrm{~min}$.

After transferring the explants into the flasks, these were sealed with aluminum foil and transparent plastic film and kept in a growth chamber with a 16-hour photoperiod, temperature of $25 \pm 2$ ${ }^{\circ} \mathrm{C}$, and light intensity of $27 \mu \mathrm{mol} \mathrm{m} \mathrm{m}^{-2} \mathrm{~s}^{-1}$, where they remained for 60 days. After the 60 days, the variables evaluated were: survival (\%), sprout length $(\mathrm{cm})$, shoot length $(\mathrm{cm})$, propagationrate, number of sprouts, and dry mass of plants $(\mathrm{g})$.

The explants that were green and presented at least two leaves were considered survivors. The propagation rate was obtained by dividing the number of buds per plant at 60 days of cultivation by the number of buds per explant at the beginning of the experiment. The length was measured with a graduated ruler. The plant dry mass for each treatment was obtained by weighing the plants that were ovendried in an oven at $50{ }^{\circ} \mathrm{C}$ until constant mass.

The $\mathrm{pH}$ and electrical conductivity of the substrates were analyzed before their transfer into the flasks and the addition of the nutritive solution following the methodology proposed by KÄMPF (2006).

The data were subjected to analysis of variance using the $F$ test $(p \leq 0.05)$. Statistical significance was further examined by Duncan's test $(p \leq 0.05)$. Table 1 is constructed from the variables that showed no interactions between the tested treatments.

\section{RESULTS AND DISCUSSION}

In all treatments $100 \%$ of the plants survived

(Table 1). One of the main aspects for the viability of 
Table 1 - Survival $(\%)$, sprout length $(\mathrm{cm})$, and shoot length $(\mathrm{cm})$ of highbush blueberry 'Duke' in the in vitro propagation phase as a function of physical structuring agents of the medium.

\begin{tabular}{|c|c|c|c|}
\hline Physical structuring agents of the medium & Survival (\%) & Sprout length $(\mathrm{cm})$ & Shoot length $(\mathrm{cm})$ \\
\hline in naturarice husks & $100^{\mathrm{ns}}$ & $0,62 \mathrm{a}^{1 / /}$ & $1,64 \mathrm{a}$ \\
\hline Carbonized rice husks & 100 & $0,54 \mathrm{ab}$ & $1,44 \mathrm{~b}$ \\
\hline Coconut fiber & 100 & $0,24 \mathrm{~b}$ & $1,26 \mathrm{~b}$ \\
\hline S-10 Beifort ${ }^{\circledR}$ & 100 & $0,81 \mathrm{a}$ & $1,25 \mathrm{~b}$ \\
\hline Agar & 100 & $0,72 \mathrm{a}$ & $1,40 \mathrm{~b}$ \\
\hline C.V. & 0 & 84,6 & 19,1 \\
\hline
\end{tabular}

${ }^{1 /}$ Averages followed by the same letter in the column do not differ according to Duncan test $(\mathrm{P} \leq 0,05) .{ }^{\text {ns. }}$ Not significant. C.V.: coefficient of variation.

micropropagation as a method of seedling production is the high plant survival (SCHUCH \& ERIG 2005). Survival is related to factors such as the type of explant, optimal hormonal balance, and adequate asepsis during the micropropagation process.

The length of sprouts in treatments within natura rice husk, carbonized rice husk, and S-10 Beifort ${ }^{\circledR}$ did not differ from that in agar cultures. In contrast, the plant shoots were longer in treatment with in natura rice husk than in treatments with the other residues and agar (Table 1). These results showed that agricultural residues can be potentially used as medium structuring agents and be more efficient for the growth of plants compared with agar.

In experiments with other fruit trees, such as the pineapple cultivar 'Vitória', the sprout survival in culture media with different structuring agents, such as pure maize (Zea mays) starch oragar with partial or total addition of starch, did not differ from that in agar media. Thus, plants cultivated in environments with corn starch showed a similar development to those cultivated in agar (OLIVEIRA et al. 2015a).

Among the tested structuring agents not supplemented with a growth regulator, S-10 Beifort ${ }^{\mathbb{B}}$ resulted in the highest propagation rate, 2.97. The propagation rate in treatments with in natura rice husks, (2.32) and carbonized rice husks (2.40) was higher than that of plants in agar medium (Table 2). This trend was observed for the number of sprouts, where the number of 0.60 sprouts per plant obtained in treatments with S-10 Beifort ${ }^{\circledR}$ was similar to those obtained with agar, in natura rice husk, and carbonized rice husk. However, when these structuring agents were supplemented with 5 and 10 $\mathrm{mg} \mathrm{L}^{-1}$ of $2 \mathrm{iP}$, the propagation rate(17.10 and 15.67$)$, sprout formation ( 3.10 and 4.0 sprouts per plant), and dry mass accumulation $(0.034$ and $0.039 \mathrm{~g})$ were the highest in treatments with agar (Table 2).

These results can be attributed to the properties of agar as a structuring agent in the culture medium and its ability to control the reactions between the nutrient solution and the medium. Agar is inert and provides $\mathrm{pH}$ stability to the medium, thereby improving the availability of nutrients and the absorption of the growth regulator. The other structuring agents present different $\mathrm{pH}$ values and electrical conductivity (Table 3 ). It is known that the interactions of salts with the medium are altered by changes in the $\mathrm{pH}$ (KÄMPF, 2006). Thus, even when the nutritive medium was added to the structuring agent at $\mathrm{pH}$ and electrical conductivity conditions optimal for the culture, cation exchange may occur, leading to alterations in electrochemical characteristics of the medium.

The better performance of agar media may be contributed to the chemical structure of the growth regulator used in this study. Namely, RODRIGUES et al. (2016) and NADAL et al. (2018), who used another class of cytokinin, the 6-benzylaminopurine (BAP), reported that certain concentrations of BAP added to coconut fiber, in natura rice husks, and carbonized rice husks promote propagation at the same level as that obtained by agar supplemented with the same concentrations of the hormone. This suggested that the regulator in the present study was retained by the structuring agents and thus made unavailable to the explant.

The $\mathrm{pH}$ values of the substrates varied from 4.8 to 6.8 , while the electrical conductivity varied from 0 to $26 \mu \mathrm{s} \mathrm{m}^{-1}$ (Table 3). Studies have showed that highbush blueberry cultures develop well in slightly acidic culture media, with $\mathrm{pH}$ around 5.0 (PELIZZA et al., 2013; SCHUCH et al., 2008). The in natura rice husk and the carbonized rice husk 
Table 2 - Propagation rate, number of sprouts, and dry mass $(\mathrm{g})$ of highbush blueberry 'Duke' in the in vitro propagation phase as a function of the concentration of 2-isopentenyladenine (2iP) and physical structuring agents of the medium.

\begin{tabular}{|c|c|c|c|}
\hline \multirow[t]{2}{*}{$\begin{array}{l}\text { Physical structuring agents of the } \\
\text { medium }\end{array}$} & & Concentration $f ?$ iP & 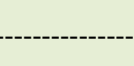 \\
\hline & $0 \mathrm{mg} \mathrm{L}^{-1}$ & $5 \mathrm{mg} \mathrm{L}^{-1}$ & $10 \mathrm{mg} \mathrm{L}^{-1}$ \\
\hline \multicolumn{4}{|c|}{ 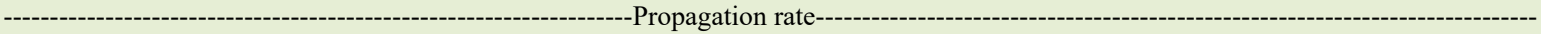 } \\
\hline in natura rice husks & $2,32 a b^{1 /} \mathrm{A}^{2 /}$ & $2,78 \mathrm{bA}$ & $2,75 \mathrm{bA}$ \\
\hline Carbonized rice husks & $2,40 \mathrm{abAB}$ & $1,68 \mathrm{bB}$ & $3,08 \mathrm{bA}$ \\
\hline Coconut fiber & $1,42 \mathrm{bA}$ & $1,52 \mathrm{bA}$ & $1,93 \mathrm{bA}$ \\
\hline S-10 Beifort ${ }^{\circledR}$ & $2,97 \mathrm{aA}$ & $2,12 \mathrm{bA}$ & $3,15 \mathrm{bA}$ \\
\hline Agar & $1,80 \mathrm{abB}$ & $17,10 \mathrm{aA}$ & $15,67 \mathrm{aA}$ \\
\hline CV & 48,5 & 40,5 & 27,4 \\
\hline \multicolumn{4}{|c|}{ 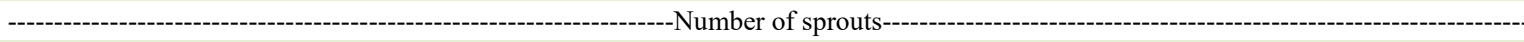 } \\
\hline in naturarice husks & $0,20 \mathrm{abA}$ & $0,17 \mathrm{bA}$ & $0,37 \mathrm{bA}$ \\
\hline Carbonized rice husks & $0,33 \mathrm{abA}$ & $0,27 \mathrm{bA}$ & $0,30 \mathrm{bA}$ \\
\hline Coconut fiber & $0,13 \mathrm{bA}$ & $0,10 \mathrm{bA}$ & $0,20 \mathrm{bA}$ \\
\hline S-10 Beifort ${ }^{\circledR}$ & $0,60 \mathrm{aA}$ & $0,47 \mathrm{bA}$ & $0,53 \mathrm{bA}$ \\
\hline Agar & $0,57 \mathrm{aB}$ & $3,10 \mathrm{aA}$ & $4,00 \mathrm{aA}$ \\
\hline C.V. & 88,3 & 66,7 & 49,1 \\
\hline \multicolumn{4}{|c|}{ 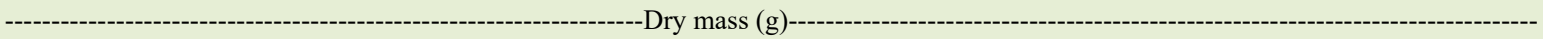 } \\
\hline in naturarice husks & $0,014 \mathrm{bA}$ & $0,006 \mathrm{bB}$ & $0,012 \mathrm{bAB}$ \\
\hline Carbonized rice husks & $0,007 \mathrm{cA}$ & $0,007 \mathrm{bA}$ & $0,009 \mathrm{bA}$ \\
\hline Coconut fiber & $0,007 \mathrm{cA}$ & $0,004 \mathrm{bA}$ & $0,004 \mathrm{cA}$ \\
\hline S-10 Beifort ${ }^{\circledR}$ & $0,012 \mathrm{bcA}$ & $0,008 \mathrm{bA}$ & $0,008 \mathrm{bcA}$ \\
\hline Agar & $0,022 \mathrm{aB}$ & $0,034 \mathrm{aAB}$ & 0,039 Аа \\
\hline C.V. & 36,5 & 48,9 & 34,9 \\
\hline
\end{tabular}

${ }^{1 /}$ Averages followed by the same lowercase letter in the column do not differ from each other according to Duncan test $\left.\mathrm{Pp} \leq 0.05\right)$. ${ }^{2 /}$ Averages followed by the same capital letter in the row do not differ from each other according to Duncan test ( $\mathrm{p} \leq 0,05)$. C.V.: coefficient of variation (\%).

had a $\mathrm{pH}$ of 6.8 , the coconut fiber and $\mathrm{S}-10$ Beifort $^{\circledR}$ had a $\mathrm{pH}$ of 4.5 and 5.8 respectively and the $\mathrm{pH}$ of agar was adjusted to 5.0.

It should be noted that the concentration of salts estimated by the electrical conductivity testing was higher in the residues than in agar (Table 3). This may have helped the development of the plants in the absence of 2iP, and may have affected the availability of the regulator when it was added to the medium.
The use of agar with the growth regulator provided the highest averages for some plant variables, whereas the medium containing S-10 Beifort ${ }^{\mathbb{R}}$, in natura rice husk, and carbonized rice husk generated plants with larger propagules. This characteristic is fundamental for the subsequent rooting process, because larger propagules generate more leaves and consequently resulted in greater photosynthetic rate, which is fundamental for plant development (TAIZ et al., 2017).

Table 3 - pH and electrical conductivity (EC) values of the substrates used.

\begin{tabular}{lccccc}
\hline Substrate & Agar & CA & CAC & FC & S-10 \\
\hline $\mathrm{pH}$ & 5 & 6,8 & 6,8 & 4,8 & 5,4 \\
$\mathrm{CE}\left(\mu \mathrm{s} \mathrm{m}^{-1}\right)$ & 0 & 2 & 6 & 26 & 10 \\
\hline
\end{tabular}

CA - in natura rice husks; CAC - carbonized rice husks; FC - coconut fiber; S-10- S-10 Beifort ${ }^{\circledR}$. 
Altogether, results suggested that the in vitro propagation of highbush blueberry 'Duke' can be conducted using agricultural residues without the supplementation with2iP. In addition, thein natura and carbonized rice husks and S-10 Beifort ${ }^{\circledR}$ are potential crop medium structuring agents, after the protocol adjustment. Finally, in pursuit of cost reduction in micropropagation, such substrates can be substituted for agar in culture media, especially in regions with abundance of these agricultural residues, thereby contributing to the reduction of their volume in the environment.

\section{CONCLUSION}

For the in vitro propagation of highbush blueberry 'Duke', thein natura rice husk, carbonized rice husk, and S-10 Beifort ${ }^{\circledR}$ are presented as potential physical structuring agents of the WPM culture medium that can be used without $2 \mathrm{iP}$.

\section{ACKNOWLEDGEMENTS}

We would like to thank CAPES (Coordenação de Aperfeiçoamento de Pessoal de Nível Superior) and $\mathrm{CNPq}$ (Conselho Nacional de Desenvolvimento Científico e Tecnológico) for providing the scholarships.

\section{DECLARATION OF CONFLICT OF INTERESTS}

The authors declare no conflict of interest. The founding sponsors had no role in the design of the study; in the collection, analyses, or interpretation of data; in the writing of the manuscript, and in the decision to publish the results.

\section{AUTHOR'S CONTRIBUTION}

1, 2 and 6 conceived and designed the experiments. 3 performed the statistical analysis of experimental data. 4, 5 assisted in conducting and evaluating the experiments. All authors critically reviewed the manuscript and approved the final version.

\section{REFERENCES}

ASSIS, A. M. de et al. Cultivo de orquídea em substratos à base de casca de café. Bragantia, Campinas, v.70, n.3, p.544-549, 2011. Available from: $\quad<\mathrm{http} / /$ www.scielo.br/scielo.php?script $=$ sci arttext\&pid $=$ S0006-87052011000300009\&lng $=$ pt\&tlng $=$ pt $>$. Accessed: Sep. 22, 2019. doi: 10.1590/S0006-87052011000300009.

CANTUARIAS-AVILES, $\mathrm{T}$. et al. Cultivo do mirtilo: atualizações e desempenho inicial de variedades de baixa exigência em frio no Estado de São Paulo. Revista Brasileira de Fruticultura, Jaboticabal, v.36, n.1, p.139-147, 2014 Available from: <http://www.scielo.br/scielo.php?pid=S0100$29452014000100015 \&$ script $=$ sci abstract\&tlng $=\mathrm{pt}>$. Accessed Sep. 22, 2019. doi: 10.1590/0100-2945-453/13.
CURTI, A. R.; REINIGER, L. R. S. Formação in vitro de raízes em canafístula: o efeito de diferentes meios de cultivo. Ciência Rural, Santa Maria, v.44, n.2, p.314-320, 2014. Available from: $<$ http://www.scielo.br/scielo.php?script=sci arttext\&pid=S0103$84782014000200019 \& \operatorname{lng}=$ pt\&tlng=pt $>$. Accessed: Sep. 22, 2019 doi: $10.1590 /$ S0103-84782014000200019

DAMIANI, C. R.; SCHUCH, M. W. Multiplicação fotoautotrófica de mirtilo através do uso de luz natural. Revista Brasileira de Fruticultura, Jaboticabal, v.30, n.2, p.482-487, 2008. Available from: <http://www.scielo.br/scielo.php?script=sci arttext\&pid $=$ S0100-29452008000200037\&lng=pt\&nrm $=$ is o\&tlng=en>. Accessed: Sep. 22, 2019. doi: 10.1590/S010029452008000200037

GOLLE, D. P. et al. Substratos alternativos e tratamentos prégerminativos na germinação in vitro de sementes de Pinus taeda L. Revista Árvore, Viçosa, v.34, n.1, p.39-48, 2010. Available from: $<$ http://www.scielo.br/scielo.php?script=sci_arttext\&pid=S0100$67622010000100005 \& \operatorname{lng}=\mathrm{pt} \& \mathrm{nrm}=\mathrm{iso} \& \mathrm{t} \operatorname{lng}=\mathrm{pt}>$. Accessed: Sep. 22, 2019. doi: 10.1590/S0100-67622010000100005.

JUnghans, T. G.; SOUZA, A. S. Aspectos práticos da micropropagação de plantas. 2ed. Brasília: Embrapa Informação Tecnológica, 2013.

KÄMPF, A. N. Floricultura: Técnicas de Preparo de Substratos. Brasília: LK, 2006.

LLOYD, G.; MCCOWN, B. Commercially-feasible micropropagation of mountain laurel, kalmia latifolia, by use of shoot-tip culture. Proceedings of the International Plant Propagator's Society, Seatle, v.30 , p.421-426, 1980. Available from: <https://www.pubhort.org/ipps/30/99.htm>. Accessed: Sep. 22, 2019.

NADAL, M. C. et al. Casca de arroz e 6-Benzilaminopurina na multiplicação in vitro de Oncidium baueri. Revista Brasileira de Ciências Agrárias (Agrária), Recife, v.13, n.3, p.1-5, 2018. Available from: <http://www.agraria.pro.br/ojs-2.4.6/index.php ?journal $=$ agraria \& page $=$ article $\&$ op $=$ view $\&$ path $\% 5 \mathrm{~B} \% 5 \mathrm{D}=\mathrm{ag}$ raria v13i3a5555>. Accessed: Sep. 22, 2019. doi: 10.5039/ agraria.v13i3a5555.

OLIVEIRA et al. Amido e hipoclorito de sódio no enraizamento in vitro do abacaxizeiro 'gold' e seus efeitos na aclimatização. Revista Brasileira de Fruticultura, Jaboticabal, v.37, n.2, p.273-280, 2015a. Available from: $<$ http:// www.scielo.br/scielo.php? script $=$ sci_arttext\&pid $=\mathrm{S} 0100$ $29452015000200273 \& \operatorname{lng}=\mathrm{pt} \& \mathrm{t} \operatorname{lng}=\mathrm{pt}>$. Accessed: Sep. 22, 2019. doi: 10.1590/0100-2945-120/14.

OLIVEIRA et al. Esterilização química e agentes geleificantes alternativos na propagação vegetativa in vitro do abacaxizeiro 'vitória'. Revista Brasileira de Fruticultura, Jaboticabal, v.37, n.4, p.819-826, 2015b. Available from: <http://www.scielo.br/scielo. php?script=sci arttext\&pid=S0100-29452015000400819\&lng=pt\& tlng=pt $>$. Accessed: Sep. 22, 2019. doi: 10.1590/0100-2945-121/14.

OLIVEIRA, L. H. et al. Resistencia biológica de painéis aglomerados produzidos a partir de resíduos agrícolas e urbanos. Revista Brasileira de Ciências Agrárias (Agrária), Recife, v.13, n.4, e5572, 2018. Available from: <http://www.agraria.pro.br/ojs2.4.6/index.php?journal=agraria \&page $=$ article $\& o p=$ view $\&$ path $\% 5 \mathrm{~B} \% 5 \mathrm{D}=$ agraria v13i4a5572>. Accessed: Sep. 22, 2019. doi: 10.5039/agraria.v13i4a5572. 
PELIZZA, T. R. et al. Estabelecimento in vitro de mirtileiro: cultivares Bluecrop, Duke e Misty. Plant Cell Culture \& Micropropagation, Lavras, v.9, n.1-2, p.24-29, 2013. Available from: <http://177.105.2.193/ojs/index.php/ PlantCellCultureMicropropagation/article/view/55>. Accessed: Sep. 22, 2019.

RETAMALES, J. B.; HANCOCK, J. F. Blueberries. 2ed. Boston: CABI, 2018.

RODRIGUES, D. B. et al. Growth regulators and substrates for Oncidium baueri Lindl. micropropagation. Semina: Ciências Agrárias, Londrina, v.37, n.5, p.2901-2910, 2016. Available from: <http://www.uel.br/revistas/uel/index.php/ semagrarias/article/view/22291>. Accessed: Sep. 22, 2019. doi: 10.5433/1679-0359.2016v37n5p2901.
SCHUCH, M. W. et al. Micropropagação como técnica de rejuvenescimento em mirtilo (Vaccinium ashei reade) cultivar climax. Ciênciae Agrotecnologia, v.32, n.3, p.814-820, 2008. Available from: <http://www.scielo.br/ scielo.php?pid $=\mathrm{S} 1413-70542008000300017 \&$ script $=$ sci abstract\&tlng=pt $>$. Accessed: Sep. 22, 2019. doi: $10.1590 /$ S1413-70542008000300017.

SCHUCH, M. W;. ERIG, A. C. Micropropagação de plantas frutíferas. In: FACHINELLO, J. C.; HOFFMANN, A.; NACHTIGAL, J. C. (Org.). Propagação de plantas frutíferas. Brasília: EMBRAPA - Informação Tecnológica, 2005. p.155-173.

TAIZ, L. et al. Fisiologia e Desenvolvimento Vegetal. 6 ed. ed. Porto Alegre: artmed, 2017. 